\title{
Part I: Insect stings and bites-Beyond the realm of bee and wasp allergies
}

\section{A survey of the literature and our own cases}

\section{Carole Guillet $(\mathbb{D} \cdot$ Oliver Yves Martin · Cordula Meincke · Lukas Joerg $(\mathbb{D}) \cdot$ Peter Schmid-Grendelmeier (iD)}

Received: 10 September 2021 / Accepted: 27 December 2021 / Published online: 17 February 2022

(C) The Author(s) 2022

\begin{abstract}
Summary
Background Insects are a very diverse group of animals and valuable members of any ecosystem. Allergies to bees and wasps (order: Hymenoptera) are well known in Europe. Allergies, toxicities, and the spread of diseases by other insects are also possible but quite frequently are not diagnosed.

Sources A MEDLINE search on allergy caused by stinging and biting insects apart from bees and wasps was conducted. All relevant articles were evaluated, and a selection of relevant publications and cases from our outpatient units are used to illustrate our arguments. Content and implications Allergies to insects following bites and stings are common. Ant stings, mainly from
\end{abstract}

Availability of data and material (data transparency) All relevant data are included in this manuscript.

Part II of this article can be found under https:// doi.org/10. 1007/s40629-022-00200-1.

C. Guillet, MD $(\varangle) \cdot$ L. Joerg, MD ·

P. Schmid-Grendelmeier, MD

Allergy Unit, Department of Dermatology, University

Hospital Zurich, Zurich, Switzerland

carole.guillet@usz.ch

C. Guillet, MD · P. Schmid-Grendelmeier, MD

Medical Faculty, University of Zurich, Zurich, Switzerland

O. Y. Martin, PhD

Department of Biology and Institute of Integrative Biology (IBZ), ETH Zurich, Zurich, Switzerland

C. Meincke, MD · L. Joerg, MD

Division of Allergology and Clinical Immunology,

Department of Pneumology, Inselspital, Bern University

Hospital, University of Bern, Bern, Switzerland

P. Schmid-Grendelmeier, MD

Christine Kühne Center for Allergy Research and Education

CK-CARE, Davos, Switzerland imported fire ants, frequently lead to severe anaphylaxis, and their venom can elicit systemic toxic effects. Stings and bites of various other ant species can also lead to severe allergic reactions. Mosquito stings and horsefly or other Diptera stings may elicit severe local and IgE-mediated systemic reactions. True bugs (Hemiptera) are hematophagous insects and can also cause severe allergic reactions, in addition to being feared for transmitting diseases.

Keywords Insect allergy · Hymenoptera · Hemiptera • Diptera $\cdot$ Sting $\cdot$ Bite

\section{Introduction}

Arthropods are a phylum of invertebrate animals, including insects, crustaceans, spiders, mites, ticks, and others. Fig. 1 provides a summary of the phylogenetic relationships within arthropods [1].

Insects are invertebrates with three pairs of legs and form the largest group within the arthropod phylum. In fact, insects are the most diverse animals on the planet, encompassing more than a million described species, thus representing over $90 \%$ of animal life forms on earth [2]. Their stings, bites, and excrements can cause mild to life-threatening allergic reactions, illicit toxic effects, lead to various skin changes and act as vectors of disease transmission. Diagnosing illness following insect stings, bites, inhalation, or ingestion can be challenging due to their often hidden character and because of mimicry of other conditions [3]. Table 1 provides an overview of allergologically relevant insects, allergy mechanisms, and typical clinical findings. 


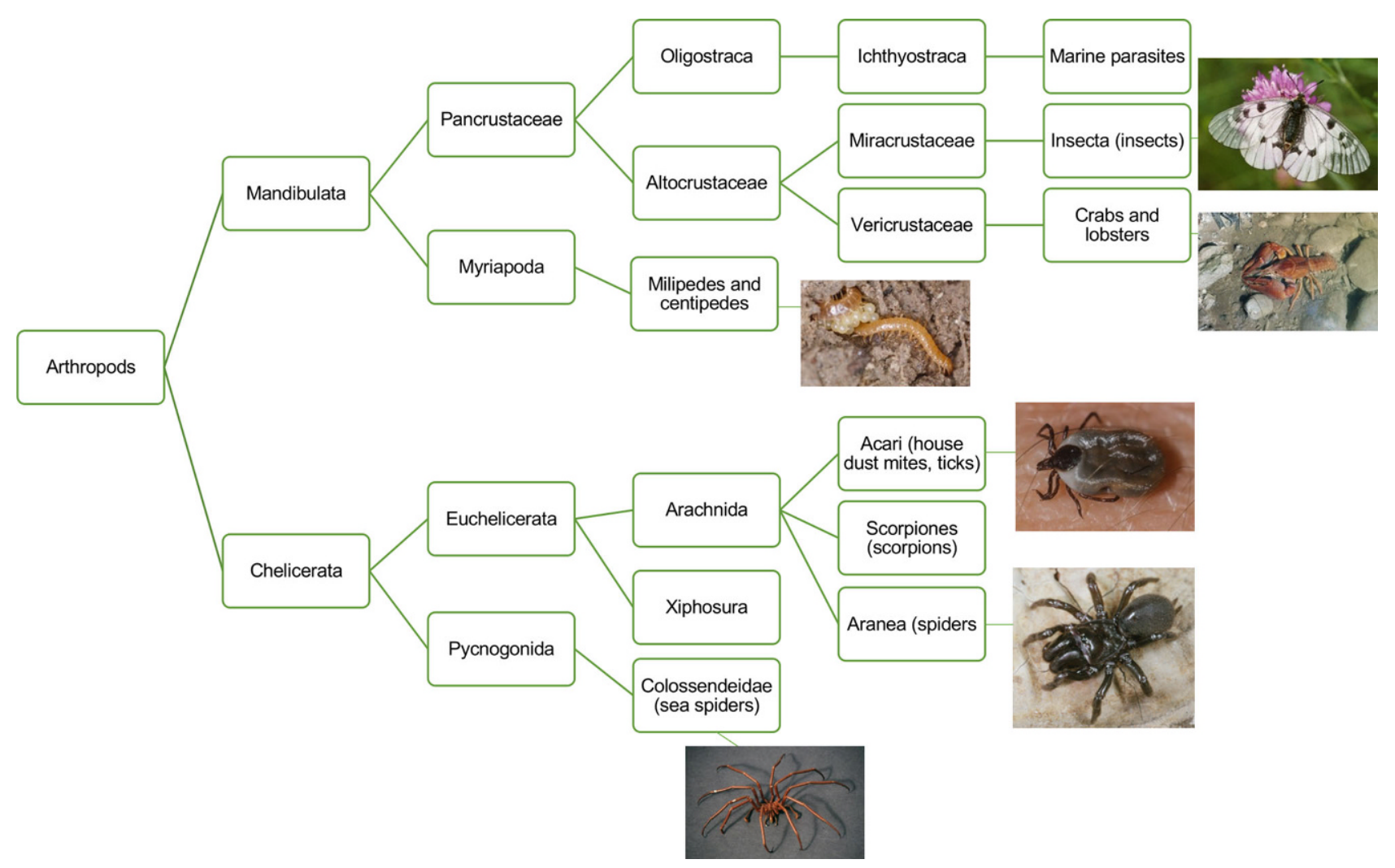

Fig. 1 Phylogenetic relationships within the arthropods. (Adapted from: Regier JC et al., Nature 2010 [1]. Images: Insecta: Clouded Apollo [Parnassius mnemosyne], Entomologie/Botanik, ETH Zürich/Photographer: Albert Krebs, CC BYSA 4.0. Crabs and lobsters: European crayfish [Astacus astacus], Entomologie/Botanik, ETH Zürich/Photographer/Albert Krebs, CC BY-SA 4.0. Millipede [Geophilus flavus]. ETH-Bib-

\section{Methods}

Search methods A literature search was conducted in PubMed in May 2021. The search terms included "Insect, allergy and/or Hymenoptera, ant, imported fire ant, Solenopsis invicta, red wood ant Formica rufa, Chinese needle ant, Pachycondyla spp., Jack jumper ant, Myrmecia spp., green-head ant, Rhytidoponera metallica, harvester ant, Pogonomyrmex spp., Solenopsis geminata, Solenopsis richteri, Solenopsis saevissima, Diptera, true flies, Neoptera, Tabanidae, Haematopoda, Chrysops, Chrysops vittatus, mosquito, Aedes aegypti, Aedes vexans, Anopheles, Plasmodium, Hemiptera, true bug, bed bug Cimex lectularis, Cimex hemipterus, Triatominnae, kissing bug, Mexican bed bug, Trypanosoma cruzii, Chagas disease, sucking lice, Pediculidae, Phthiraptera, fleas, Siphonaptera”. Pivotal papers describing initial descriptions of allergies to above-mentioned insect orders, families or species, newest insights, papers by key opinion leaders, and society guidelines were considered. Additional studies were identified using bibliographical information contained in selected articles. Articles regarding bee and wasp allergies were deliberately not covered in detail in this article. liothek Zürich, Bildarchiv/Photographer: Keller, Siegfried, CC BY-SA 4.0. Acari: Hard bodied tick [lxodes sp.], ETH-Bibliothek Zürich, Bildarchiv/Photographer/Keller, Siegfried, CC BY-SA 4.0. Aranea: Purseweb spider [Atypus sp.], Entomologie/Botanik, ETH Zürich/Photographer/Albert Krebs, CC BYSA 4.0. Colosseneidae: Sea spider [Pycnogonida]. Joy Viola, Northeastern University, Bugwood.org, with permission)

Case description Illustrative cases from our outpatient clinics are also included.

\section{Results}

\section{Hymenoptera-Bees, wasps, and ants}

Allergic reactions to hymenopteran venoms after stings or bites, especially bee and wasp stings, are common and a leading cause of anaphylaxis in Europe [4]. The order Hymenoptera also includes the family Formicidae, e.g., the imported fire ant (Solenopsis invicta; IFA) or the red wood ant (Formica rufa). Ants are a very diverse family, consisting of 22 subfamilies encompassing more than 14,000 species [5]. A comparatively small number of ants have been identified to cause allergic reactions, including specific IgEmediated allergies to various venom proteins [6].

Like many ant species, the red wood ant (Formica rufa) has lost its stinging ability during evolution. However, it has a powerful chewing apparatus and can inject its venom directly into the bite wound [7].

Native to South America and introduced in North America from the middle of the 20th century, the IFA is known for its excruciating sting and the ability to 


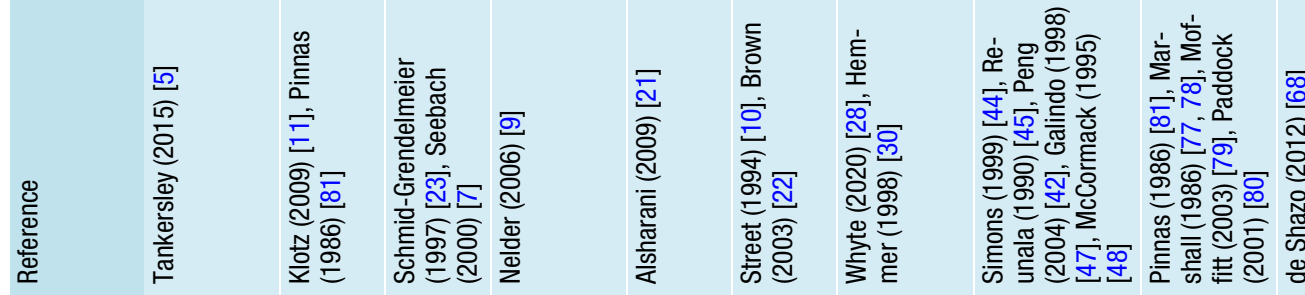

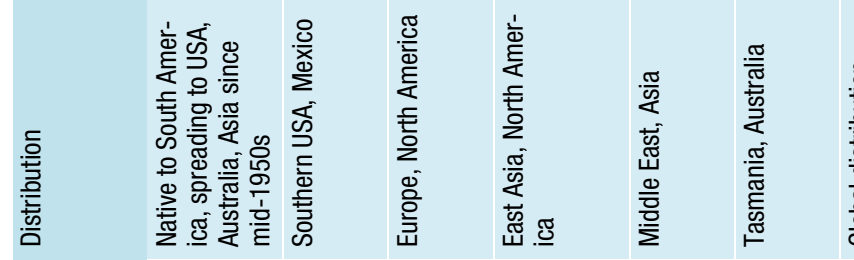

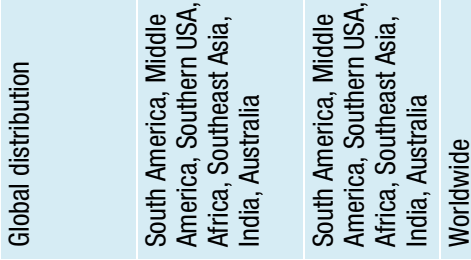

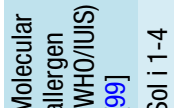

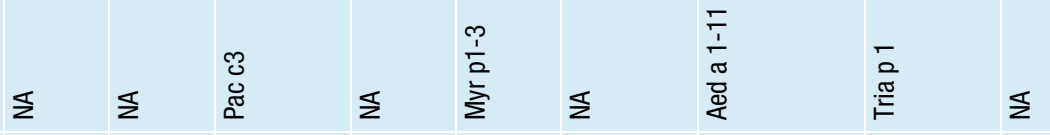
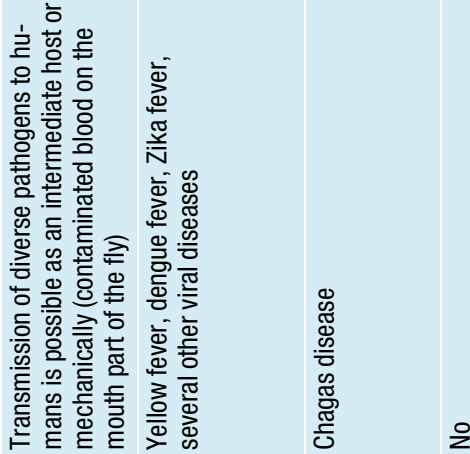

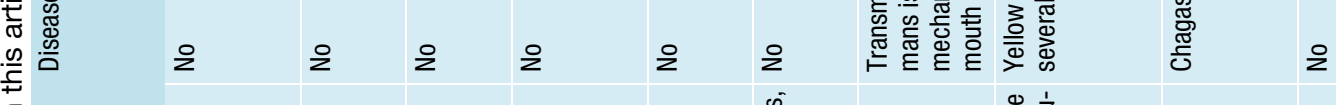
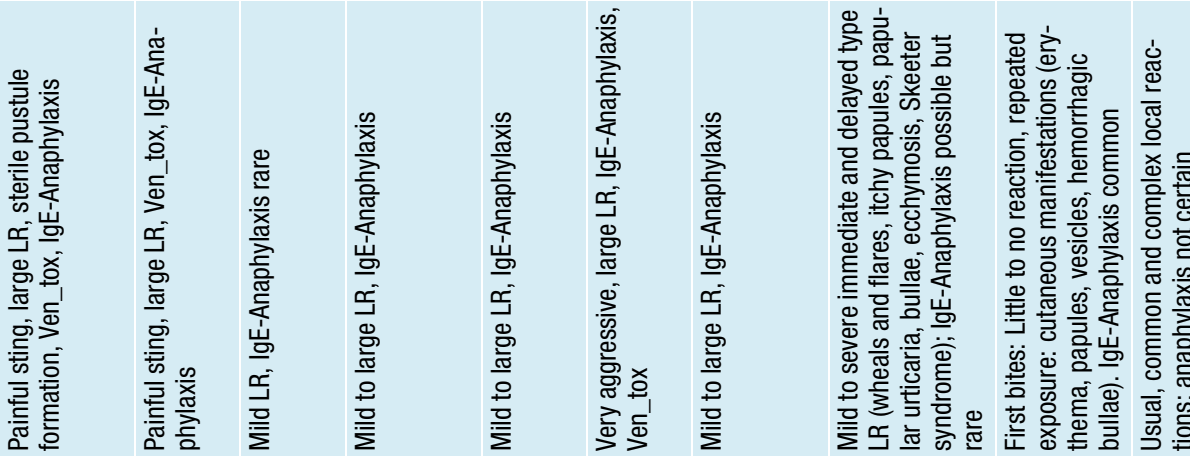

荧

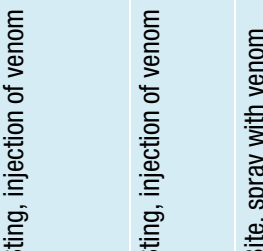

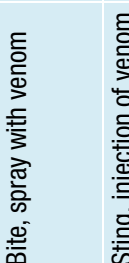
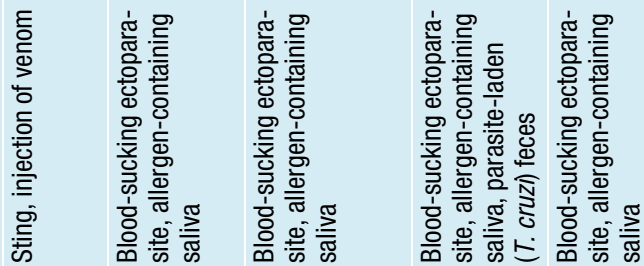

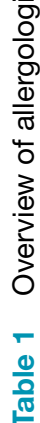

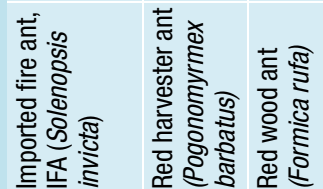

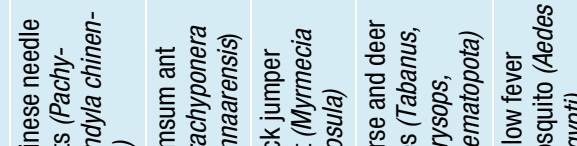

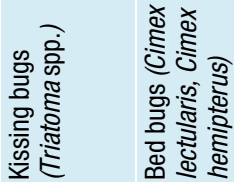

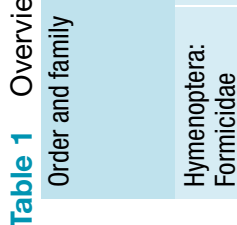

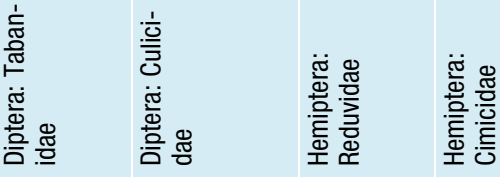




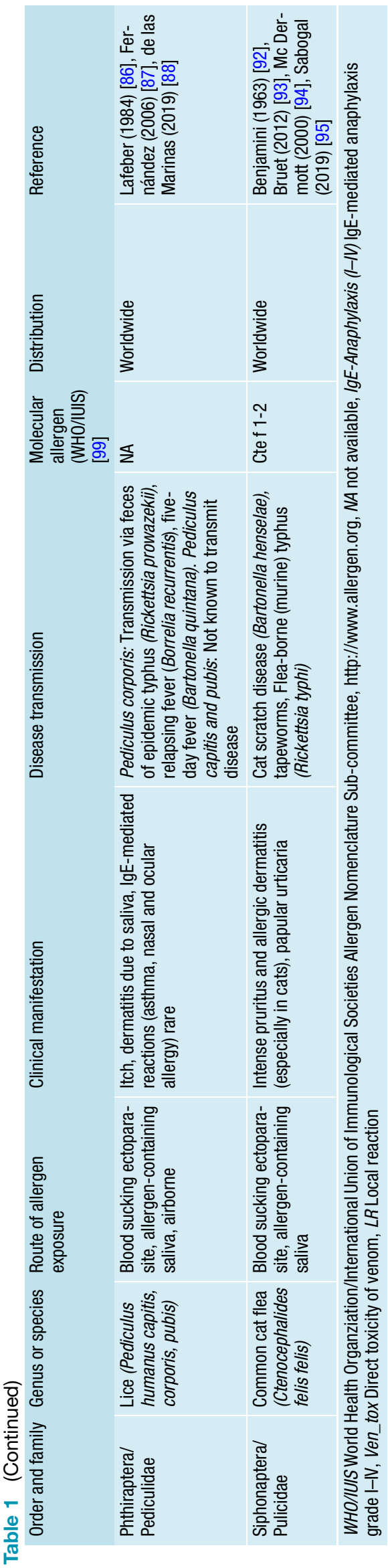

cause severe, IgE-mediated anaphylaxis. Due to the effects of global warming, which increases climatic suitability for the IFA and reduces the resistance of native ant communities, this invasive species has spread to the United States, the Caribbean, and some Asian countries and is also invading Australia and parts of New Zealand. IFA is the most common cause of antinduced allergic reactions worldwide [8]. Allergies to ants other than IFA are less common.

In Southeast Asia, imported fire ants and Chinese needle ants (Pachycondyla spp.), in Australia, Jack jumper ants (Myrmecia spp.) and Green-head ants (Rhytidoponera metallica), and in the USA, the harvester ant (Pogonomyrmex spp.) can also cause allergies [9-11]. Some cases of allergies induced by the red wood ant (Formica rufa), endemic in Europe and North America, have also been reported [7].

After an IFA sting, a dermal flare with wheal, a small vesicle, or a sterile pustule develops within minutes to hours due to direct toxic effects of the ant venom and tissue inflammation caused by the venom ([12]; Fig. 2). The IFA venom is composed of alkaloids, which explains sterile pustule formation after stings [5]. Some patients (17 to 56\%) develop a large local reaction consisting of an extremely large and pruritic lesion persisting for up to $72 \mathrm{~h}$ [13]. IgE-mediated severe allergic reactions following IFA stings are well documented and sometimes even lead to severe endorgan damage, including rhabdomyolysis, renal failure, and neurotoxic effects, which can also be induced by direct toxic effects of multiple ant stings [14-17].

The diagnosis of immediate-type hypersensitivity to ants is made by correlating the clinical manifestations of the sting reactions with ant-specific IgE determined by skin testing and/or radioallergosorbent test. Major protein allergens were isolated from IFA venoms (Sol I 1-4) and several allergens from other Solenopsis species (Sol g2-4 from Solenopsis geminata, Sol r2-3 from Solenopsis richteri, and Sol s2-3 from Solenopsis saevissima), the Australian jack jumper ant (Myr p1-3, Myrmecia pilosula) and the Asian needle ant (Pac c3, Pachycondyla chinensis) [8]. Whole-body extracts contain relevant venom allergens and can be used for skin testing and immunotherapy for IFA allergy, Jack jumper ant allergy, Chinese needle ant allergy, and Samsum ant allergy ([18-22].
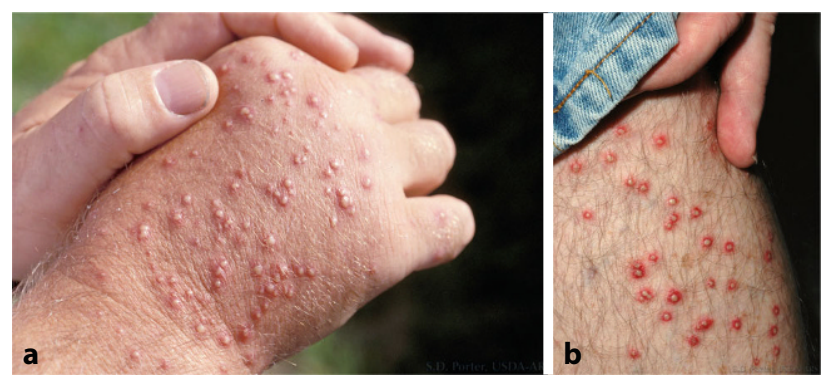

Fig. 2 Sterile pustules on hand (a) and leg (b) after fire ant sting. (Sanford Porter, with permission) 


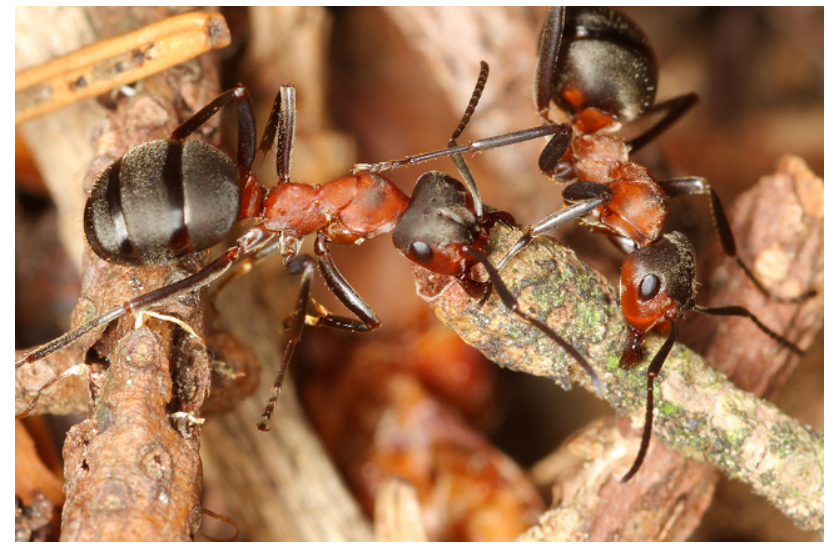

Fig. 3 Red wood ant (Formica rufa). (Beat Wermelinger, WSL, with permission)

The following two cases of ant allergy stem from the outpatient department in Zurich [7, 23]:

Case 1: Anaphylaxis due to a redwood ant (Formica rufa) bite A 12-year-old boy sustained an ant bite during $a$ in the forest in September. Prior ant bites and bee and wasp stings had been tolerated well. The boy developed flushing, generalized urticaria, and severe dyspnea only minutes after being bitten. He required treatment with bronchodilators and corticosteroids. Subsequently, the ant that patient had preserved after being stung was identified as a redwood ant (Formica rufa) by an entomologist. A skin prick test with a wholebody extract of red wood ant produced a large wheal and flare. Specific IgE against red wood ant was positive $(1.8 \mathrm{U} / \mathrm{ml})$ and thus, anaphylaxis to a red wood ant bite was diagnosed (Fig. 3).

Case 2: Anaphylaxis due to a red fire ant (Solenopsis invicta) sting A 56-year-old woman developed generalized urticaria and angioedema after being stung by an ant during a holiday in Florida. We strongly suspected a red fire ant venom allergy, as these ants are endemic to Florida and the patient could identify the ants from photos. Diagnostic testing performed in Switzerland showed sensitizations to wasp and hornet allergens measured by ImmunoCAP. Specific IgE to fire ant (i70) was negative. One year after this episode, another sting occurred in Florida, causing more severe anaphylaxis (grade III according to Ring \& Messmer; [24]). The consecutively performed skin prick test with commercially available whole-body extract was strongly positive, and specific IgE to Sol $i 1$ was now positive. However, it remains unclear why IFA-specific IgE and skin testing were negative at the first presentation. Specific venom immunotherapy was initiated following a rush protocol. A sting was well tolerated after the immunotherapy was stopped after five years of continuous treatment (Fig. 4).

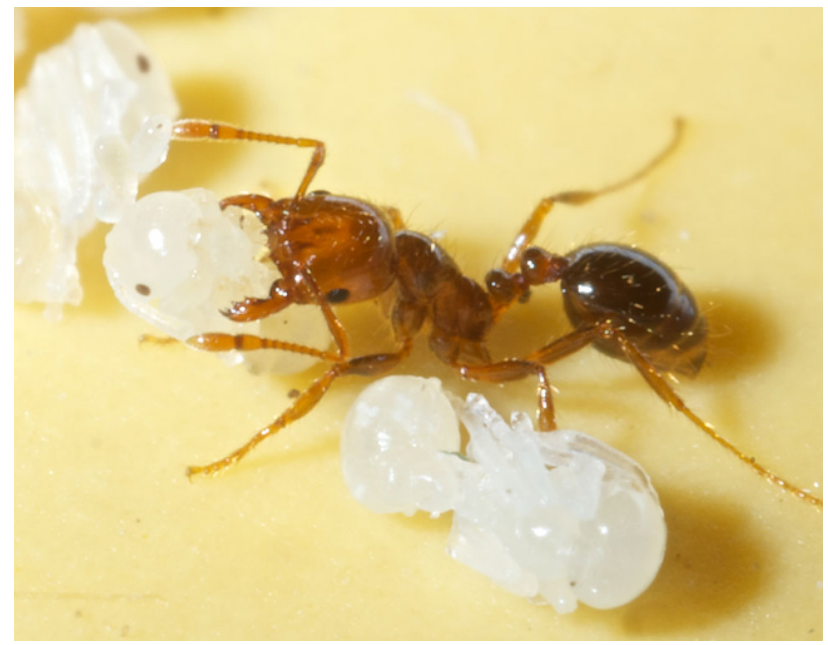

Fig. 4 Red fire ant (Solenopsis invicta). (Sanford Porter, with permission)

\section{Diptera-True flies}

Diptera, or true flies, occur in numerous habitats and have spread to all continents [25]. Numerous hematophagous insects belong to this order, with representatives of the Tabanidae and mosquitoes being particularly relevant in medicine. Respiratory and occupational allergies to Diptera, e.g., common houseflies or fruit flies, are rare [26, 27].

\section{Tabanidae-Horse flies and deer flies}

The family Tabanidae contains about 4500 species and subspecies and has a worldwide distribution [27]. The clinically most relevant representatives of the Tabanidae family belong to the genera Tabanus and Chrysops, all of which occur in Central Europe ([28]; Fig. 5). Local reactions after a tabanid bite are common, but anaphylaxis and systemic symptoms are rare $[28,29]$. There are only single cases and small case series describing allergies to Tabanidae [28, 30-35]. Tabanid allergens in saliva are still incompletely characterized. Only three allergens have been identified so far, some of which overlap with mosquito and wasp venom allergens [36]. The diagnosis of an allergy to tabanids is therefore difficult. In cases with significant local reactions, no further investigation is necessary. In patients with anaphylaxis, prick tests are possible, albeit not standardized. A whole-body extract for Chrysops vittatus is commercially available (Stallergenes Greer, London, UK). The same limitation applies to in vitro tests, where sensitivity and specificity remain unclear. Although specific immunotherapy was performed in individual cases $[37,38]$, extracts are not commercially available or standardized and are usually performed using whole-body extracts.

Case 3: Anaphylaxis due to a horsefly (Tabanus eggeri) sting A 35-year-old woman was stung on the 


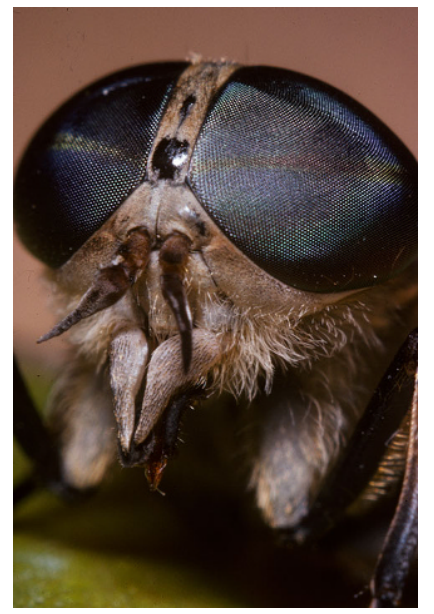

Fig. 5 Pale giant horse-fly (Tabanus bovinus). (ETH-Bibliothek Zürich, Bildarchiv/Fotograf: Keller, Siegfried, CC BYSA 4.0)

back of the head by an insect while bathing in a lake in Switzerland. She identified the insect herself as a horsefly. Minutes after the sting, severe itching occurred on the head, spreading rapidly to the whole body. Generalized urticaria and angioedema in the facial region quickly appeared, followed by hypotension $(80 \mathrm{~mm} \mathrm{Hg}$, systolic) and bradycardia. Emergency treatment consisted of intravenously administered epinephrine, volume administration, antihistamines, and systemic steroids. The tryptase in the acute event was $14.4 \mu \mathrm{g} / \mathrm{l}$, the basal value measured later was $4.6 \mu \mathrm{g} / \mathrm{l}$. Skin test solution for tabanids was not available, specific IgE against horsefly $(0.45 \mathrm{kU} / \mathrm{L})$ was positive, and thus the diagnosis of anaphylaxis following a horsefly sting was made.

\section{Culicidae-Mosquitoes}

Mosquitoes (Nematocera) are insects within the Diptera order and encompass more than 3500 species worldwide [39, 40]. In allergology, the most important mosquito species are Aedes aegypti and Aedes vexans [41]. Allergic reactions to mosquito bites are caused by sensitization to mosquito salivary antigens [40, 42]. Specific IgE and IgG antibodies and T-cell mediated delayed-type hypersensitivity reactions are involved in the pathogenesis of mosquito allergy [43]. Common reactions to mosquito stings include immediatetype reactions minutes after the sting, consisting of wheals and flares and delayed reactions manifesting 24 to $36 \mathrm{~h}$ after the sting as itchy papules. Late type reactions manifest as vesicles, bullae, ecchymosis, and even Skeeter syndrome and Arthus-type local and systemic reactions [44, 45]. Albeit rare, severe anaphylaxis to mosquito stings is also possible [46-48].

Different mosquito saliva proteins were identified as potential allergens. A correlation of immediate type reactions and mosquito bite-induced anaphylaxis with elevations of serum-specific IgE levels was shown [43]. Immunoassays using recombinant mosquito salivary allergens (rAed a one and rAed a 3) are sensitive and specific for the diagnosis of mosquito allergy [42].

Nevertheless, diagnosing mosquito allergy remains challenging. Skin prick reagents commercially used for diagnosing mosquito allergy contain whole body parts of mosquito and small concentrations of allergenic saliva proteins [49]. To date, no robust studies could prove the effect of desensitization with wholebody extract in treating mosquito allergic patients. Therefore, the most important treatment of mosquito allergy remains prevention from being stung using repellents and mosquito nets. Studies suggest that natural desensitization in mosquito-allergic children may occur during adolescence [46].

In addition to mosquito allergies, bacterial superinfections resulting from scratching itchy lesions after a bite, and transmission of pathogens such as Plasmodium (malaria) transmitted by Anopheles spp. mosquitoes or Flaviviridae (the causes of yellow fever or dengue fever) are of global health importance [50, 51].

Other Nematocera families like Ceratopogonidae (e.g., biting midges) and Chironomidae have been shown to have allergenic potential both after stinging humans and also as airborne allergens $[52,53]$.

\section{Hemiptera-True bugs}

Hemiptera, or true bugs, are an insect order within the Neoptera. In 2008, there were 82,000 described species, and the total number of species worldwide was estimated to be over 200,000 [54]. Allergic reactions following bed bug (Cimex lectularius) and kissing bug (subfamily Triatominae) bites are common, but lesser-known true bugs can also cause allergies when used as food additives, such as cochineal lice (Dactylopius coccus) or lac bugs (Kerria lacca) [55-58]. Reactions to insects and insect compounds as food will be further discussed in part II of this article. Hemiptera are also important vectors of diseases such as Chagas disease, where kissing bugs transmit the parasite Trypanosoma cruzi [59].

\section{Cimicidae-Bed bugs}

Bed bugs such as Cimex lectularis or C. hemipterus were nearly eradicated in Western countries in the 1940s due to pesticides. However, a re-emergence of bed bugs began in the mid-1990s, and their infestation is currently increasing and spreading worldwide [60-62]. Partially, their re-emergence may be due to a resistance to pesticides [63].

Bed bugs are nocturnal bloodsuckers that can live up to 1 year without feeding. The primary hosts are humans and other mammals. Bed bugs are insensitive to cold and die only at temperatures above $41{ }^{\circ} \mathrm{C}$ [64]. Due to their small size and adjustability, bed bugs can hide in small loopholes in mattresses or wallpaper and 


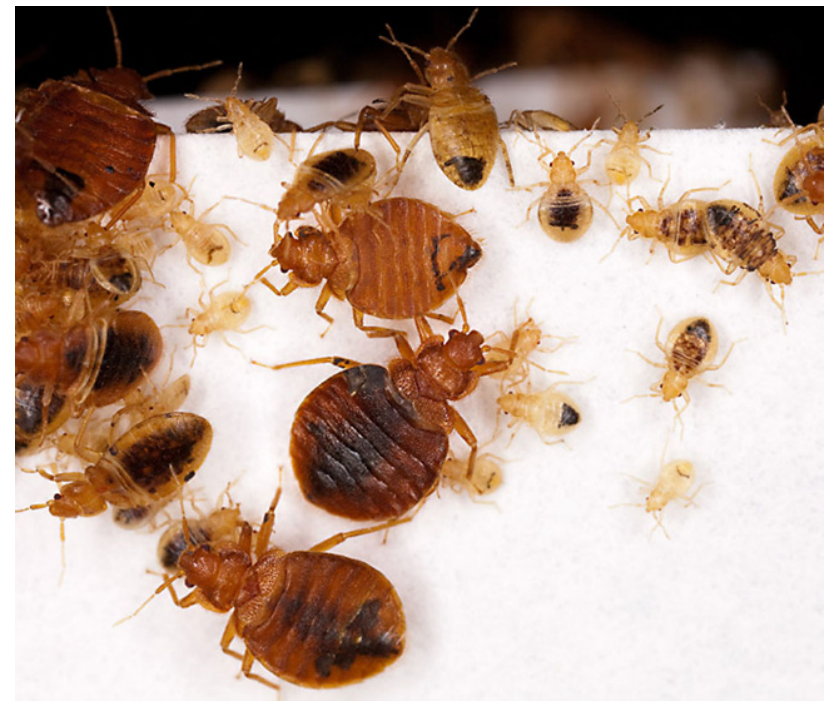

Fig. 6 Bed bugs (Cimex lectularis). (Photo by Stephen Ausmus, USDA Agricultural Research Service, with permission)

travel long distances, for example, in suitcases [65]. The bed bug's bite usually occurs at night and is not noticed at first due to the anesthetic effect of its saliva.

A bed bug bite may give rise to localized cutaneous responses of various manifestations and anaphylactic reactions of different grades [64, 66, 67]. Classification of cutaneous reactions after bed bug bites has been proposed (i.e., usual, common, and complex reactions) [68]. "Usual reactions" occur within one hour and consist of pruritus and no local reaction save for punctiform visibility of the bite site. "Common reactions" occur within hours and manifest as pruritic macules or papules resembling papular urticaria. "Complex reactions" are bullous, pruritic, and may be painful and persist for several days [68-72].

Bullous rashes occurring days after stings could represent late-phase responses of IgE-mediated hypersensitivity [66, 73]. However, severe immediatetype anaphylactic reactions have not been documented with certainty, but sometimes multiple stings can imitate the picture of generalized urticaria, and one case of severe anaphylaxis following bed bug bite mimicking acute coronary syndrome was reported in 2006 [69]. Salivary proteins of bed bugs (nitrophorin, factor X, apyrase-like nucleotide-binding enzymes) are of immunological importance, and specific IgEs to C. lectularis crude extract and C. lectularius nitrophorin recombinant protein can be present in individuals with a history of bed bug bites [55, 74-76]. The use of high-potency topical corticosteroids and oral antihistamines is the treatment of choice in local bullous reactions, and severe reactions may even require systemic corticosteroids ([68]; Fig. 6).

\section{Triatominae-Kissing bugs}

Triatomine insects (also called: kissing bugs, Mexican bed bugs, and cone-nosed bugs) are found mainly in the western and southern United States, Central

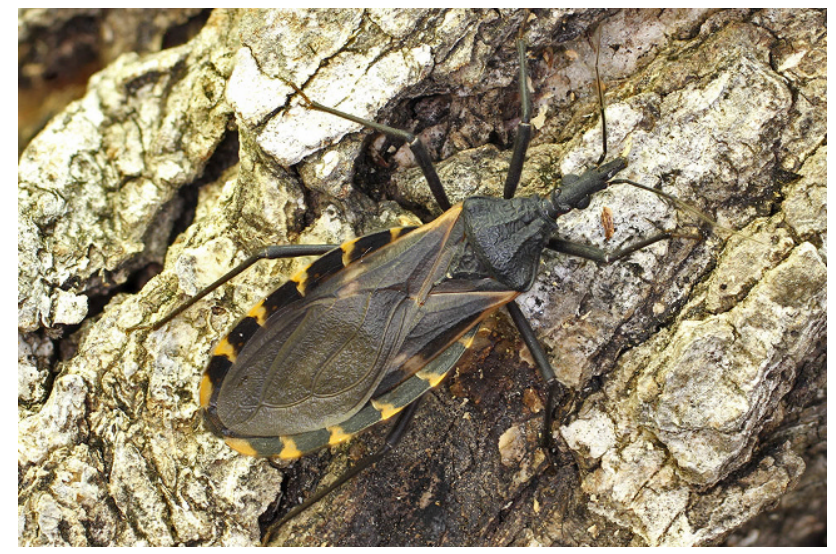

Fig. 7 Assassin bug (Triatoma gerstaeckeri). (Gabriel Hamer, Texas A\&M University, with permission)

and South America, and Mexico (Fig. 7). They are ectoparasites on small mammals and feed on their blood. Bites usually occur on exposed body parts (face, hands, feet) at night and are painless. Kissing bug bites are among the common causes of insectbite-related allergies [77, 78]. Initial bites produce little to no reaction, and repeated exposure leads to a range of local reactions with variable presentation (erythema, papules, vesicles, hemorrhagic bullae). In addition to cutaneous hypersensitivity reactions, lifethreatening immediate-type reactions have been described ("nocturnal anaphylaxis") [79].

The primary allergen identified in triatomine saliva is a $20 \mathrm{kDa}$ protein, which interestingly belongs to the same protein family (lipocalins) as known of inhalation allergens of dogs, cats, and other mammals [80]. Reactivity to two salivary gland extracts of two Triatominae species was demonstrated and immunotherapy using a salivary gland extract showed benefits in a small patient cohort. No commercial testing or treatment allergen is available [81, 82]. While feeding, triatomines defecate parasiteladen feces and can transmit Trypanosoma cruzii, the causative organism of Chagas disease [56].

\section{Phthiraptera-Sucking lice}

Body lice and head lice (Pediculus humanus humanus and Pediculus humanus capitis) and pubic lice (Pthirus pubis) are hematophagous ectoparasites of humans living on the scalp, body, and pubic or on other areas with coarse hair ([83-85]; Fig. 8). They feed on mammalian blood and cause pediculosis capitis, pediculosis corporis, or pediculosis pubis in humans. Infestation with lice leads to itching, with sometimes eczema caused by the saliva of the parasites. Head lice spend their entire life cycle on their hosts and are not transmitted by pets as vectors. Head lice are 


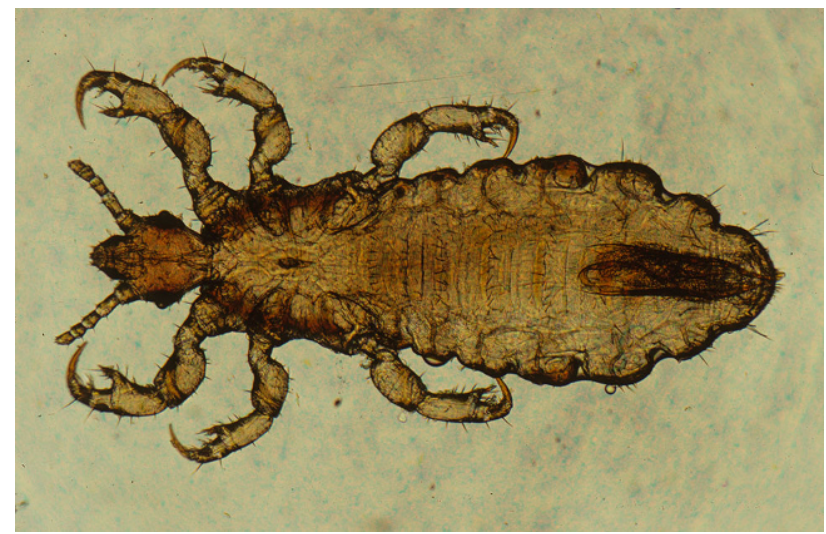

Fig. 8 Head louse (Pediculus humanus capitis). (ETH-Bibliothek Zürich, Bildarchiv/Photographer: Keller, Siegfried, CC BY-SA 4.0)

a widespread infestation, especially in children. Few allergic reactions to head lice have been described, including one case of allergic asthma and one case of nasal and ocular allergy induced by a specific IgEmediated reaction to louse body proteins [86-88]. To date, no allergic reactions to the body or pubic lice have been reported.

\section{Siphonaptera-Fleas}

Fleas are small blood-sucking ectoparasites [89] and include more than 2500 species. Fleas play an essential role in veterinary medicine since they frequently lead to allergic flea dermatitis in cats and dogs (FAD) [89]. The common cat flea (Ctenocephalides felis felis) is mainly responsible for the development of allergic flea dermatitis ([90]; Fig 9). Albeit rarer, flea allergic dermatitis can also manifest in humans, especially those more commonly exposed to ectoparasites, e.g., homeless people [91]. After a flea bite, the components of flea saliva (polypeptides, phosphorus, amino acids, aromatic amines) cause severe pruritus and papules, crusts, and excoriations [92]. In veteri-

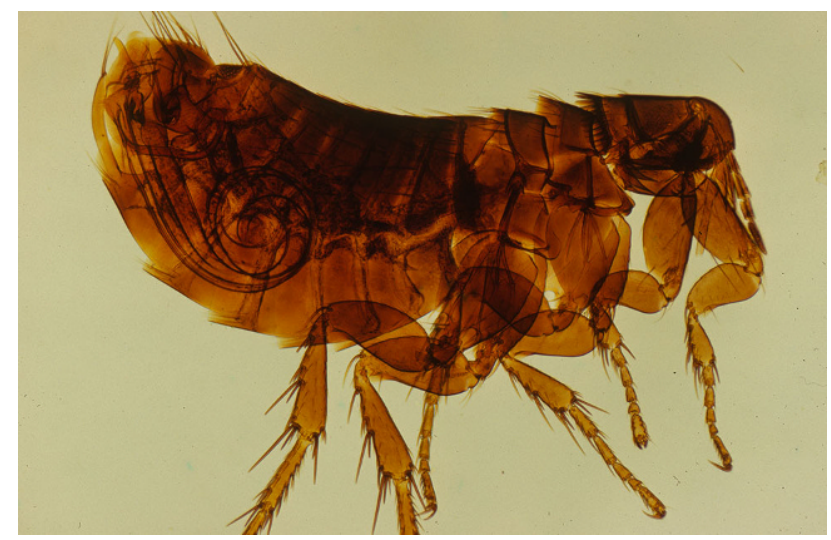

Fig. 9 Cat flea (Ctenocephalides felis). (ETH-Bibliothek Zürich, Bildarchiv/Phottographer: Keller, Siegfried, CC BYSA 4.0) nary medicine, an intradermal skin test with glycerinated flea antigens can be used to diagnose FAD [93]. Cte $\mathrm{f} 1$ and Cte $\mathrm{f} 2$ are the major allergens described from Ctenocephalides felis [94].

In humans, papular urticaria after a flea bite is common [95-97]. In children living in areas where flea bites frequently induce papular urticaria, like in South America, Cte f 2 induces both IgE and IgG production as well as T-cell proliferation [95]. Furthermore, disease transmission by fleas is possible in humans, cats, and dogs, e.g., flea-borne murine typhus [98].

\section{Conclusion}

Allergic reactions and direct poisoning following insect stings or bites are common, occur worldwide, and are associated with significant morbidity. Ant stings and bites, especially from imported fire ants, can cause severe anaphylaxis, and their venom can lead to systemic poisoning and end-organ damage. Mosquito and tabanid stings but also as inhaled allergens rarely trigger IgE-mediated reactions. True bugs, such as bed bugs or kissing bugs, are nuisance pests that can cause allergies but can also be a vector for disease transmission, such as kissing bugs causing Chagas disease. Other blood-sucking insects like lice and fleas often cause dermatitis, papular urticaria, whereas severe IgE-mediated reactions are infrequent. Allergic reactions following insect stings or bites may not be detected or diagnosed if the causative insect cannot be identified. For this reason, patients should be encouraged to keep causative insects for identification and diagnostic testing. In uncertain cases, an entomologist should be consulted.

\section{Funding No funding to declare}

Author Contribution C. Guillet: Conception and design, acquisition of data, interpretation, drafting of the manuscript, final approval; O.Y. Martin: Conception and design, acquisition of data and visuals, drafting of the manuscript, critical revision of the manuscript for important intellectual content, final approval; C. Meincke: Critical revision of the manuscript for important intellectual content, final approval; L. Joerg: Acquisition of data, drafting and critical revision of the manuscript for important intellectual content, final approval, P. SchmidGrendelmeier: Conception and design, acquisition of data and visuals, drafting of the manuscript, critical revision of the manuscript for important intellectual content, final approval.

Funding Open access funding provided by University of Zurich

Conflict of interest P. Schmid-Grendelmeier has acted as consultant or speaker for Bühlmann Laboratory, Euroimmun, and Thermo Fisher; Research grants received from Bühlmann Laboratories and Thermo Fisher. C. Guillet, O.Y. Martin, C. Meincke and L. Joerg declare that they have no competing interests.

Open Access This article is licensed under a Creative Commons Attribution 4.0 International License, which permits use, sharing, adaptation, distribution and reproduction in 
any medium or format, as long as you give appropriate credit to the original author(s) and the source, provide a link to the Creative Commons licence, and indicate if changes were made. The images or other third party material in this article are included in the article's Creative Commons licence, unless indicated otherwise in a credit line to the material. If material is not included in the article's Creative Commons licence and your intended use is not permitted by statutory regulation or exceeds the permitted use, you will need to obtain permission directly from the copyright holder. To view a copy of this licence, visit http://creativecommons.org/licenses/by/4.0/.

\section{References}

1. Regier JC, Shultz JW, Zwick A, Hussey A, Ball B, Wetzer R, et al. Arthropod relationships revealed by phylogenomic analysis of nuclear protein-coding sequences. Nature. 2010;463:1079-83. https://doi.org/10.1038/nature08742.

2. Roques A, Auger-Rozenberg M-A, Blackburn TM, Garnas JR, Pyšek P, et al. Temporal and interspecific variation in rates of spread for insect species invading Europe during the last 200 years. Biol Invasions. 2016;18:907-20.

3. Steen CJ, Carbonaro PA, SchwartzRA. Arthropodsin dermatology. JAm Acad Dermatol. 2004;50:819-42. quiz 842-814. https://doi.org/10.1016/j.jaad.2003.12.019

4. Sampson HA, Muñoz-FurlongA, BockSA, SchmittC, Bass R, Chowdhury BA, et al. Symposium on the definition and management of anaphylaxis: summary report. J Allergy Clin Immunol. 2005;115:584-91. https:// doi.org/10.1016/ j.jaci.2005.01.009.

5. Tankersley MS, Ledford DK. Stinging insect allergy: state of the art 2015. J Allergy Clin Immunol Pract. 2015;3:315-22. quiz323. https:// doi.org/10.1016/j.jaip.2015.03.012

6. Aili SR, Touchard A, Escoubas P, Padula MP, Orivel J, Dejean A, et al. Diversity of peptide toxins from stinging ant venoms. Toxicon. 2014;92:166-78. https://doi.org/10. 1016/j.toxicon.2014.10.021

7. Seebach JD, Bucher C, Anliker M, Schmid-Grendelmeier P, Wüthrich B. Ant venoms: a rare cause of allergic reactions in Switzerland. Schweiz Med Wochenschr. 2000;130:1805-13.

8. Stafford CT. Hypersensitivity to fire ant venom. Ann Allergy Asthma Immunol. 1996;77:87-95. quiz 96-89. https://doi. org/10.1016/S1081-1206(10)63493-X.

9. Nelder MP, Paysen ES, Zungoli PA, Benson EP. Emergence of the introduced ant pachycondyla chinensis (formicidae: ponerinae) as a public health threat in the southeastern United States. J Med Entomol. 2006;43:1094-8. https://doi.org/10.1603/00222585(2006)43[1094:eotiap]2.0.co;2

10. Street MD, Donovan GR, Baldo BA, Sutherland S. Immediate allergic reactions to myrmecia ant stings: immunochemical analysis of myrmecia venoms. Clin Exp Allergy. 1994;24:590-7. https://doi.org/10.1111/j.1365-2222.1994. tb00957.x.

11. Klotz JH. Anaphylactic reactions to arthropod bites and stings. 2009.

12. Stafford CT. Fire ant allergy. Allergy Proc. 1992;13:11-6. https://doi.org/10.2500/108854192778878971.

13. deShazo RD, Griffing C, Kwan TH, Banks WA, Dvorak HF. Dermal hypersensitivity reactions to imported fire ants. J Allergy Clin Immunol. 1984;74:841-7. https:// doi.org/ 10. 1016/0091-6749(84)90188-x.

14. Koya S, Crenshaw D, Agarwal A. Rhabdomyolysis and acute renal failure after fire ant bites. J Gen Intern Med. 2007;22:145-7. https://doi.org/10.1007/s11606006-0025-z.
15. Lee YC, Wang JS, Shiang JC, Tsai MK, Deng KT, Chang MY, et al. Haemolytic uremic syndrome following fire ant bites. BMC Nephrol. 2014;15:5. https://doi.org/10.1186/14712369-15-5.

16. Cochran J, McSwain SD, Evans M, Webb S, Tecklenburg F. Anaphylaxis and delayed hymenoptera in a child with fire ant envenomation. Am J Emerg Med. 2013;31:632.e1-632.e3. https://doi.org/10.1016/j.ajem. 2012.09.022.

17. More DR, Kohlmeier RE, Hoffman DR. Fatal anaphylaxis to indoor native fire ant stings in an infant. Am J Forensic Med Pathol. 2008;29:62-3. https://doi.org/10.1097/PAF. 0b013e3181651b53.

18. Srisong H, Daduang S, Lopata AL. Current advances in ant venom proteins causing hypersensitivity reactions in the Asia-Pacific region. Mol Immunol. 2016;69:24-32. https:// doi.org/10.1016/j.molimm.2015.11.003.

19. Dib G, Guerin B, Banks WA, Leynadier F. Systemic reactions to the Samsum ant: an IgE-mediated hypersensitivity. J Allergy Clin Immunol. 1995;96:465-72. https://doi.org/10.1016/s0091-6749(95)70288-1.

20. Kim SS, Park HS, Kim HY, Lee SK, Nahm DH. Anaphylaxis caused by the new ant, pachycondyla chinensis: demonstration of specific IgE and IgE-binding components. J Allergy Clin Immunol. 2001;107:1095-9. https://doi.org/10. 1067/mai.2001.114341.

21. Alsharani M, Alashahrani M, Alanazi M, Alsalamah M. Black ant stings caused by pachycondyla sennaarensis: a significant health hazard. Ann Saudi Med. 2009;29:207-11. https://doi.org/10.5144/0256-4947.2009.207.

22. Brown SG, Wiese MD, Blackman KE, Heddle RJ. Ant venom immunotherapy: a double-blind, placebo-controlled, crossover trial. Lancet. 2003;361:1001-6. https:// doi.org/10.1016/S0140-6736(03)12827-9.

23. Schmid-Grendelmeier P, Lundberg M, Wüthrich B. Anaphylaxis due to a red harvest ant bite. Allergy. 1997;52:230-1. https://doi.org/10.1111/j.1398-9995.1997.tb00982.x.

24. Ring J, Messmer K. Incidence and severity of anaphylactoid reactions to colloid volume substitutes. Lancet. 1977;1:466-9. https://doi.org/10.1016/s01406736(77)91953-5.

25. Merritt RW, Courtney GW, Keiper JB. Encyclopedia of insects. 2nd ed. 2009.

26. Focke M, Hemmer W, Wöhrl S, Götz M, Jarisch R, Kofler H. Specific sensitization to the common housefly (musca domestica) not related to insect panallergy. Allergy. 2003;58:448-51. https://doi.org/10.1034/j.1398-9995. 2003.00126.x.

27. Jones M, Blair S, MacNeill S, Welch J, Hole A, Baxter P, et al. Occupational allergy to fruit flies. Occup Environ Med. 2017;74:422-5. https://doi.org/10.1136/oemed2016-103834.

28. Whyte AF, Popescu FD, Carlson J. Tabanidae insect (horsefly and deerfly) allergy in humans: a review of the literature. Clin Exp Allergy. 2020;50:886-93. https://doi.org/10.1111/ cea.13677.

29. VeraldiS, Esposito L. Skinlesions caused by tabanus bovinus bites. J Travel Med. 2017; https://doi.org/10.1093/jtm/ tax049.

30. Hemmer W, Focke M, Vieluf D, Berg-Drewniok B, Götz M, Jarisch R. Anaphylaxis induced by horsefly bites: identification of a $69 \mathrm{kd}$ IgE-binding salivary gland protein from chrysops spp. (diptera, tabanidae) by western blot analysis. J Allergy Clin Immunol. 1998;101:134-6. https://doi.org/10.1016/S0091-6749(98)70208-8. 
31. Quercia O, Emiliani F, Foschi FG, Stefanini GF. A case of anaphylaxis: horse-fly or hymenoptera sting? Eur Ann Allergy Clin Immunol. 2009;41:152-4.

32. Potier A, Lavigne C, Chappard D, Verret JL, Chevailler A, Nicolie B, et al. Cutaneous manifestations in hymenoptera and diptera anaphylaxis: relationship with basal serum tryptase. Clin Exp Allergy. 2009;39:717-25. https:// doi.org/ 10.1111/j.1365-2222.2009.03210.x.

33. Quercia O, Emiliani F, Foschi FG, Stefanini GF. The wasphorsefly syndrome. Eur Ann Allergy Clin Immunol. 2008;40:61-3.

34. Solley GO. Allergy to stinging and biting insects in Queensland. Med J Aust. 1990;153:650-4. https:// doi.org/10.5694/ j.1326-5377.1990.tb126312.x.

35. Solley GO. Stinging and biting insect allergy: an Australian experience. Ann Allergy Asthma Immunol. 2004;93:532-7. https://doi.org/10.1016/S1081-1206(10)61259-8.

36. Ma D, Li Y, Dong J, An S, Wang Y, Liu C, et al. Purification and characterization of two new allergens from the salivary glands of the horsefly, tabanus yao. Allergy. 2011;66:101-9. https://doi.org/10.1111/j.1398-9995.2010.02435.x.

37. Wilbur RD, Evans R. An immunologic evaluation of deerfly hypersensitivity. J Allergy Clin Immunol. 1975;55:72-3.

38. Hrabak TM, Dice JP. Use of immunotherapy in the management of presumed anaphylaxis to the deer fly. Ann Allergy Asthma Immunol. 2003;90:351-4. https://doi.org/10.1016/S1081-1206(10)61806-6.

39. Becker N, et al. Mosquitoes and their control. 2nd ed. New York, NY: Springer; 2010.

40. CrispHC,Johnson KS. Mosquito allergy. AnnAllergyAsthma Immunol. 2013;110:65-9. https://doi.org/10.1016/j.anai. 2012.07.023.

41. Peng Z, Li H, Simons FE. Immunoblot analysis of salivary allergens in 10 mosquito species with worldwide distribution and the human IgE responses to these allergens. J Allergy Clin Immunol. 1998;101:498-505. https://doi.org/10.1016/S0091-6749(98)70357-4.

42. Peng Z, Beckett AN, Engler RJ, Hoffman DR, Ott NL, Simons FE. Immune responses to mosquito saliva in 14 individuals with acute systemic allergic reactions to mosquito bites. J Allergy Clin Immunol. 2004;114:1189-94. https:// doi.org/10.1016/j.jaci.2004.08.014.

43. Peng Z, Yang M, Simons FE. Immunologic mechanisms in mosquito allergy: correlation of skin reactions with specific IgE and IgG antibodies and lymphocyte proliferation response to mosquito antigens. Ann Allergy Asthma Immunol. 1996;77:238-44. https://doi.org/10.1016/S10811206(10)63262-0.

44. Simons FE, Peng Z. Skeeter syndrome. J Allergy Clin Immunol. 1999;104:705-7. https://doi.org/10.1016/s00916749(99)70348-9.

45. Reunala T, Brummer-Korvenkontio H, Lappalainen P, Räsänen L, Palosuo T. Immunology and treatment of mosquito bites. Clin Exp Allergy. 1990;20(4):19-24. https://doi.org/ 10.1111/j.1365-2222.1990.tb02472.x.

46. PengZ, Ho MK, Li C, Simons FE. Evidence for natural desensitization to mosquito salivary allergens: mosquito saliva specific IgE and IgG levels in children. Ann Allergy Asthma Immunol. 2004;93:553-6. https://doi.org/10.1016/s10811206(10)61262-8.

47. Galindo PA, Gómez E, Borja J, Feo F, García R, Lombardero M, et al. Mosquito bite hypersensitivity. Allergol Immunopathol (Madr). 1998;26:251-4.

48. McCormack DR, Salata KF, Hershey JN, Carpenter GB, Engler RJ. Mosquito bite anaphylaxis: immunotherapy with whole body extracts. Ann Allergy Asthma Immunol. 1995;74:39-44.
49. Khurana T, Bridgewater JL, Rabin RL. Allergenic extracts to diagnose and treat sensitivity to insect venoms and inhaled allergens. Ann Allergy Asthma Immunol. 2017;118:531-6. https://doi.org/10.1016/j.anai.2016.05.026.

50. Halbach R, Junglen S, van Rij RP. Mosquito-specific and mosquito-borne viruses: evolution, infection, and host defense. Curr Opin Insect Sci. 2017;22:16-27. https://doi. org/10.1016/j.cois.2017.05.004.

51. Graumans W, Jacobs E, Bousema T, Sinnis P. When is a plasmodium-infected mosquito an infectious mosquito? Trends Parasitol. 2020;36:705-16. https://doi.org/10.1016/ j.pt.2020.05.011.

52. Chen YH, Lee MF, Tsai JJ, Wu HJ, Hwang GY. Specific IgE and IgG responses and cytokine profile in subjects with allergic reactions to biting midge forcipomyia taiwana. Int ArchAllergy Immunol. 2009;150:66-74.https:// doi.org/ 10. 1159/000210382.

53. BaurX. Chironomid midge allergy. Arerugi. 1992;41:81-5.

54. Capinera JL et al. editor. Encyclopedia of Entomology. 2nd ed. Springer Publishing, New York, NY, 2008.

55. Price JB, Divjan A, Montfort WR, Stansfield KH, Freyer GA, Perzanowski MS. IgE against bed bug (cimex lectularius) allergens is common among adults bitten by bed bugs. J Allergy Clin Immunol. 2012;129:863-865.e2. https://doi. org/10.1016/j.jaci.2012.01.034.

56. Klotz JH, Dorn PL, Logan JL, Stevens L, Pinnas JL, Schmidt JO, et al. "Kissing bugs": potential disease vectors and cause of anaphylaxis. Clin Infect Dis. 2010;50:1629-34. https:// doi.org/10.1086/652769.

57. Kägi MK, Wüthrich B, Johansson SG. Campari-Orange anaphylaxis due to carmine allergy. Lancet. 1994;344:60-1. https://doi.org/10.1016/s0140-6736(94)91083-9.

58. Guillet C, Schmid-Grendelmeier P. Reply to 'A case of anaphylactic shock induced by mealworm antigen in the bite of a Japanese flying squirrel' by Seshimo et al. JEur Acad Dermatol Venereol. 2021;35(9):e617-e8. https://doi.org/ $10.1111 /$ jdv.17411.

59. Pérez-Molina JA, Molina I. Chagas disease. Lancet. 2018;391(10115):82-94. https://doi.org/10.1016/S01406736(17)31612-4.

60. EddyC, Jones SC. Bed bugs, publichealth, and social justice: part 1, a call to action. JEnviron Health. 2011;73:8-14.

61. Alalawi AH. Bed bugs epidemic in the United States. EntomolOrnithol Herpetol. 2014;4:1.

62. Boase C. Bedbugs- reclaiming our cities. Biologist. 2004;51(1):9-12.

63. Punchihewa R, de Silva WAPP, Weeraratne TC, Karunaratne SHPP. Insecticide resistance mechanisms with novel ' $k d r$ ' type gene mutations in the tropical bed bug cimex hemipterus. Parasit Vectors. 2019;12:310. https:// doi.org/10.1186/s13071-019-3565-x.

64. Goddard J, deShazo R. Bed bugs (cimex lectularius) and clinical consequences of their bites. JAMA. 2009;301(13):1358-66. https://doi.org/10.1001/jama. 2009.405 .

65. Harlan HJ. Bed bugs 101: the basics of Cimexlectularius. Am Entomol. 2006;52:99-101

66. Parsons DJ. Bedbug bite anaphylaxis misinterpreted as coronary occlusion. Ohio State Med J. 1955;51:669.

67. Sheele JM. Association between bed bugs and allergic reactions. Parasite Immunol. 2021;43(7):e12832. https:// doi.org/10.1111/pim.12832.

68. deShazo RD, Feldlaufer MF, Mihm MC, Goddard J. Bullous reactions to bedbug bites reflect cutaneous vasculitis. Am J Med. 2012;125(7):688-94. https://doi.org/10.1016/j. amjmed.2011.11.020. 
69. Scarupa MD, Economides A. Bedbug bites masquerading as urticaria. J Allergy Clin Immunol. 2006;117(6):1508-9. https://doi.org/10.1016/j.jaci.2006.03.034.

70. Tharakaram S. Bullous eruption due to cimex lecticularis. Clin Exp Dermatol. 1999;126:241-2. https://doi.org/10. 1046/j.1365-2230.1999.00467.x.

71. Fletcher CL, Ardern-Jones MR, Hay RJ. Widespread bullous eruption due to multiple bed bug bites. Clin Exp Dermatol. 2002;27(1):74-5. https://doi.org/10.1046/j.0307-6938. 2001.00967.x.

72. Liebold K, Schliemann-Willers S, Wollina U. Disseminated bullous eruption with systemic reaction caused by cimex lectularius. J Eur Acad Dermatol Venereol. 2003;17(4):461-3. https://doi.org/10.1046/j.1468-3083. 2003.00778.x.

73. Leverkus M, Jochim RC, Schäd S, Bröcker EB, Andersen JF, Valenzuela JG, et al. Bullous allergic hypersensitivity to bed bug bites mediated by IgE against salivary nitrophorin. J Invest Dermatol. 2006;126(1):91-6. https://doi.org/10. 1038/sj.jid.5700012.

74. Valenzuela JG, Ribeiro JM. Purification and cloning of the salivarynitrophorinfrom thehemipteran cimexlectularius. JExp Biol. 1998;201:2659-64.

75. Valenzuela JG, Charlab R, Galperin MY, Ribeiro JM. Purification, cloning, and expression of an apyrase from the bed bug cimex lectularius. A new type of nucleotide-binding enzyme. J Biol Chem. 1998;273(46):30583-90. https://doi. org/10.1074/jbc.273.46.30583.

76. Valenzuela JG, Guimaraes JA, Ribeiro JM. A novel inhibitor of factor Xactivation from the salivary glands of the bed bug cimex lectularius. Exp Parasitol. 1996;83:184-90. https:// doi.org/10.1006/expr.1996.0065.

77. Marshall NA, Chapman MD, Saxon A. Species-specific allergens from the salivary glands of triatominae (heteroptera:reduviidae). J Allergy Clin Immunol. 1986;78:430-5. https://doi.org/10.1016/00916749(86)90029-1.

78. Marshall N, Liebhaber M, Dyer Z, Saxon A. The prevalence of allergic sensitization to triatoma protracta (heteroptera: reduviidae) in a southern California, USA, community. J Med Entomol. 1986;23:117-24. https://doi.org/10.1093/ jmedent/23.2.117.

79. Moffitt JE, Venarske D, Goddard J, Yates AB, deShazo RD. Allergic reactions to triatoma bites. Ann Allergy Asthma Immunol. 2003;91(2):122-8. quiz 128-130, 194. https://doi.org/10.1016/S1081-1206(10)62165-5.

80. Paddock CD, McKerrow JH, Hansell E, Foreman KW, Hsieh I, Marshall N. Identification, cloning, and recombinant expression of procalin, a major triatomine allergen. J Immunol. 2001;167:2694-9. https://doi.org/10.4049/ jimmunol.167.5.2694.

81. Pinnas JL, Lindberg RE, Chen TM, Meinke GC. Studies of kissing bug-sensitive patients: evidence for the lack of cross-reactivity between triatoma protracta and triatoma rubida salivary gland extracts. J Allergy Clin Immunol. 1986;77:364-70. https://doi.org/10.1016/s00916749(86)80119-1.

82. Rohr AS, Marshall NA, Saxon A. Successful immunotherapy for triatoma protracta-induced anaphylaxis. J Allergy Clin Immunol. 1984;73:369-75. https://doi.org/10.1016/00916749(84)90410-x.

83. Roberts RJ. Clinical practice. Head lice. N Engl J Med. 2002;346:1645-50. https://doi.org/10.1056/ NEJMcp012640.
84. Ko CJ, Elston DM. Pediculosis. J Am Acad Dermatol. 2004;50:1-12. quiz 13-14. https://doi.org/10.1016/s01909622(03)02729-4.

85. Patel PU, Tan A, Levell NJ. A clinical review and history of pubic lice. Clin Exp Dermatol. 2021;46(7):1181-8. https:// doi.org/10.1111/ced.14666.

86. Lafeber A. An allergic reaction from contact with pediculus humanus capitis (head lice). Ned Tijdschr Geneeskd. 1984;128:1860-1.

87. Fernández S, Fernández A, Armentia A, Pineda F. Allergy due to head lice (pediculus humanus capitis). Allergy. 2006;61:1372. https://doi.org/10.1111/j.1398-9995.2006. 01179.x.

88. de las Marinas Alvarez MD, Martorell Calatayud C, Castillo Fernandez M, Alvariño Martín M, Félix Toledo R, Cerdá Mir JC, et al. Allergic rhinoconjunctivitis due to pediculus humanus capitis. J Investig Allergol Clin Immunol. 2019;29:296-8. https://doi.org/10.18176/jiaci.0375.

89. Sousa CA. Fleas, flea allergy, and flea control: a review. DermatolOnlineJ. 1997;3:7.

90. Harman DW, Halliwell RE, Greiner EC. Flea species from dogs and cats in north-central Florida. Vet Parasitol. 1987;23:135-40. https://doi.org/10.1016/03044017(87)90031-8.

91. Youssefi MR, Ebrahimpour S, Rezaei M, Ahmadpour E, Rakhshanpour A, Rahimi MT. Dermatitis caused by ctenocephalides felis (cat flea) in human. Caspian J Intern Med. 2014;5:248-50.

92. Benjamini E, Feingold BF, Young JD, Kartman L, Shimizu M. Allergy to flea bites. IV. In vitro collection and antigenic properties of the oral secretion of the cat flea, ctenocephalides felis felis (Bouche). Exp Parasitol. 1963;13:143-54. https://doi.org/10.1016/00144894(63)90064-x.

93. Bruet V, Bourdeau PJ, Roussel A, Imparato L, Desfontis JC. Characterization of pruritus in canine atopic dermatitis, flea bite hypersensitivity and flea infestation and its role in diagnosis. VetDermatol. 2012;23:487-e93. https://doi.org/ 10.1111/j.1365-3164.2012.01092.x.

94. McDermott MJ, Weber E, Hunter S, Stedman KE, Best E, Frank GR, et al. Identification, cloning, and characterization of a major cat flea salivary allergen (Cte f 1). Mol Immunol. 2000;37:361-75. https://doi.org/10.1016/s01615890(00)00061-4

95. Sabogal P, Lozano A, Mercado D, Cantillo JF, Moncada L, Quiñones ML, et al. Cellular and humoral responses to Cte f2, a cat flea allergen, in children with papular urticaria. Int Arch Allergy Immunol. 2019;179:89-101. https://doi.org/ $10.1159 / 000496743$

96. Lozano AM, López JF, Zakzuk J, García E. Papular urticaria: a review of causal agents in Colombia. Biomedica. 2016;36:632-45. https://doi.org/10.7705/biomedica. v36i4.3258.

97. Cuéllar A, Rodríguez A, Halpert E, Rojas F, GómezA, Rojas A, et al. Specific pattern of flea antigen recognition by IgG subclass and IgE during the progression of papular urticaria caused by flea bite. Allergol Immunopathol (Madr). 2010;38:197-202. https://doi.org/10.1016/j.aller. 2009.09.012.

98. Caravedo Martinez MA, Ramírez-Hernández A, Blanton LS. Manifestations and management of flea-borne Rickettsioses. Res Rep Trop Med. 2021;12:1-14.https://doi. org/10.2147/RRTM.S274724.

99. WHO/IUIS: World Health Organziation/ International Union of Immunological Societies Allergen Nomenclature Sub-committee, http://www.allergen.org 